\title{
PREMATURE OVARIAN FAILURE (POF) IN BRAZILIAN FRAGILE X CARRIERS
}

\author{
Angela M. Vianna-Morgante, Silvia S. Costa, Rita de C.M. Pavanello, \\ P.A. Otto and Regina C. Mingroni-Netto
}

\begin{abstract}
The gynecological and reproductive histories of 193 women from fragile $X$ families were surveyed. Among the 101 carriers of the premutation, 14 experienced premature menopause, contrarily to their 37 fully mutated and 55 noncarrier female relatives. Although premature menopause showed a tendency to cluster in certain fragile $X$ families, as a group, the premutated women experienced menopause earlier than noncarriers. This suggests that premature menopause may be the extreme effect of a spectrum of ovarian anomalies associated with the fragile $\mathrm{X}$ premutation.
\end{abstract}

\section{INTRODUCTION}

Fragile $\mathrm{X}$ syndrome is the most prevalent form of inherited mental retardation. In most cases, the mutation consists of an amplification of a CGG repeat in the 5' untranslated region of the FMR1 gene at Xq27, a region normally polymorphic, wherein the number of repeats ranges from 6 to 50. Among mentally retarded individuals, however, the number of repeats exceeds 200. This fully mutated allele is abnormally hypermethylated and is not transcribed. Lack of the gene product, FMRP, an RNA-binding protein, appears to cause the syndrome. Intermediate-sized alleles with 50 to 200 repeats are called premutations. Transcription does not seem to be impaired among premutation carriers, who are not mentally retarded. However, these alleles are unstable and tend to expand when transmitted from parent to child. (Oberlé et al., 1991, Pieretti et al., 1991; Ashley, 1993).

Premature ovarian failure (POF), the complete cessation of ovarian function before age 40 , has been described both in patients with $\mathrm{X}$ chromosome abnormalities and in association with a normal karyotype. Familial cases show a clear pattern of dominant inheritance, with expression restricted to females (Mattison et al., 1984). A possible association of the fragile $\mathrm{X}$ premutation with premature ovarian failure was first reported by Cronister et al. (1991), who found eight women with POF among 61 normal fra $(X)$ heterozygotes. In a multicenter study of obstetrical and gynecological complications in fra(X) carriers, Schwartz et al. (1994) observed that premutated carriers had POF $(25 \%)$ more frequently than noncarriers (6\%). Vianna-Morgante et al. (1996) described a threegeneration family in which POF segregated with the premutation. In 1995, during the 7th International Workshop on Fragile X and X-Linked Mental Retardation held

Departamento de Biologia, Instituto de Biociências, Universidade de São Paulo, Caixa Postal 11461, 05422-970 São Paulo, SP, Brasil. Send correspondence to A.M.V.-M. in Trфmso, Norway, an international collaboration project was created to investigate this association. Nine centers, surveying a total of 760 women from fragile $\mathrm{X}$ families, disclosed a significant association between fragile $\mathrm{X}$ premutation and premature menopause (AllinghamHawkins et al., 1999). Here we report our study of 193 Brazilian women from fragile $\mathrm{X}$ families surveyed about their fragile $X$ carrier status and their menstrual and reproductive histories. Part of these data were included in the international study previously cited.

\section{MATERIAL AND METHODS}

Families with the fragile $\mathrm{X}$ mutation were ascertained in the Genetic Counseling Service of the Departamento de Biologia, IB-USP, through mentally retarded individuals. All women 25 years of age and older who had undergone carrier testing using molecular methodology were contacted and interviewed by one of us (AMVM) about their menstrual, gynecological and reproductive histories. Premature ovarian failure was considered as complete cessation of menstrual periods, for at least one year, prior to age 40 . Women who had undergone hysterectomy before age 40 were excluded from the study. The final sample consisted of 193 women: 101 premutated, 37 fully mutated and 55 noncarriers.

Carrier status of the women was determined by Southern blotting. DNA extracted from whole blood was doubly digested with EcoRI/EagI and probed with $S t \mathrm{~B} 12.3$, as previously described (Mingroni-Netto et al., 1994).

\section{RESULTS}

Our data are summarized in Table I. Among the 101 premutated females, 14 (13.9\%) experienced menopause before age 40, compared with none of the 37 fully mutated $(\mathrm{P}=0.02$; Fisher's exact test) and 55 noncarrier females $(P=0.002)$. The mean age at menopause in the premutated group $(39.4 \pm 10.3)$ was significantly lower than among noncarriers $(50.6 \pm 4.8 ; \mathrm{P}<0.01$; Dunn's multiple comparisons test), but the fully mutated $(49.3 \pm 2.9)$ 
and noncarrier females did not differ. Figure 1 shows the distribution of premutated women according to their ages at menopause, whose median is well below that of noncarriers. It seems, therefore, that premutated females, as a group, experience menopause earlier than noncarriers. Age at menarche was similar in the three groups.

As shown in Table II, premutated women may experience POF as early as age 13 , with complete cessation of menses occurring in the majority (10/14) under age 35 . Their age at menopause ranged from age 13 to $38(28.5 \pm 8.19)$. Ten of these had premutated relatives and in five of these families other premutated females were found to have experienced POF. Therefore, POF may cluster in certain fragile $\mathrm{X}$ families.

\section{DISCUSSION}

Our study shows that a significantly higher proportion of premutated carriers experience premature menopause compared to fully mutated and noncarrier women in fragile $\mathrm{X}$ families. The frequency of POF reported herein among premutated females is significantly

Table I - Frequency of POF in fragile X carriers.

\begin{tabular}{|lccc|}
\hline & \multicolumn{2}{c}{ Carriers } & \multirow{2}{*}{ Noncarriers } \\
\cline { 2 - 3 } & Premutation & Full mutation & \\
\hline Number & 101 & 37 & 55 \\
Mean age (years) & 42.34 & 36.61 & 40.39 \\
SD & 11.80 & 9.38 & 12.68 \\
Mean age at menarche (years) & 12.67 & 11.99 & 12.82 \\
SD & 1.65 & 1.11 & 1.50 \\
Mean age at menopause (years) & $39.39(\mathrm{~N}=37)^{\mathrm{a}}$ & $49.25(\mathrm{~N}=4)$ & $50.60(\mathrm{~N}=10)$ \\
SD & 10.31 & 2.99 & 4.79 \\
Mean & $28.50(\mathrm{~N}=14)^{\mathrm{b}}$ & & \\
SD & 8.19 & & \\
Mean & $46.01(\mathrm{~N}=23)^{\mathrm{c}}$ & & \\
SD & 3.61 & & \\
POF (females $\geq 40$ years) & $8 / 49$ & $0 / 8$ & $0 / 21$ \\
POF (females $<40$ years) & $6 / 52$ & $0 / 29$ & $0 / 34$ \\
POF (all females) & $14 / 101$ & $0 / 37$ & $0 / 55$ \\
\hline
\end{tabular}

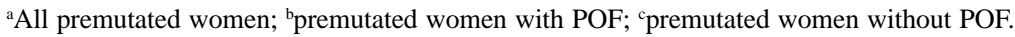

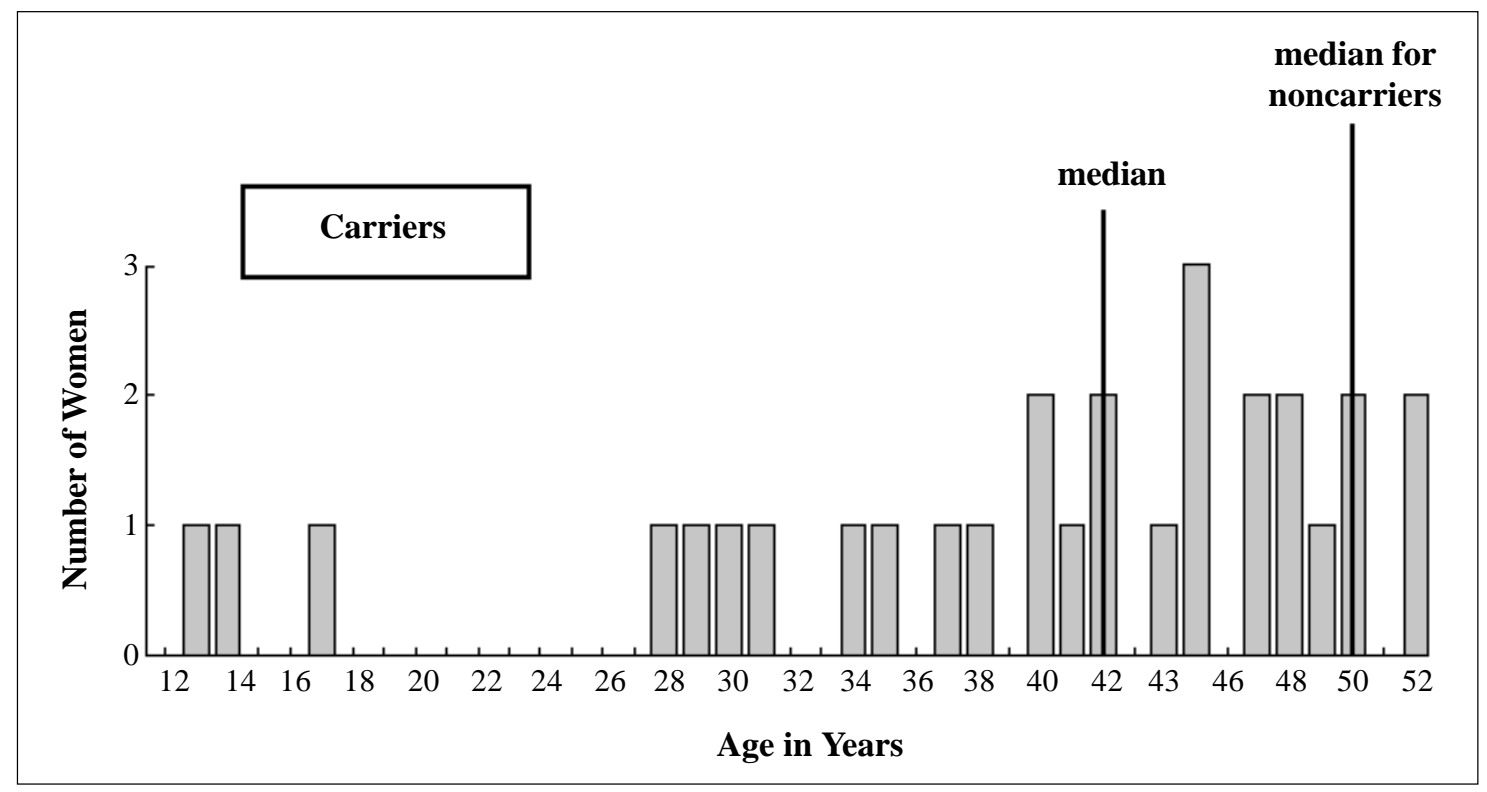

Figure 1 - Distribution of carriers of the fragile $\mathrm{X}$ premutation according to age at menopause. The difference between their median age at menopause and that of noncarriers indicates that premutated women are prone to early menopause. 
Table 2 - Premutated women with POF.

\begin{tabular}{|c|c|c|c|c|c|c|c|}
\hline & \multirow{3}{*}{$\begin{array}{c}\text { Age } \\
\text { (years) }\end{array}$} & \multirow{3}{*}{$\begin{array}{c}\text { Menarche } \\
\text { (years) }\end{array}$} & \multirow{3}{*}{$\begin{array}{c}\text { Menopause } \\
\text { (years) }\end{array}$} & \multicolumn{4}{|c|}{ Premutated relatives } \\
\hline & & & & \multicolumn{2}{|c|}{$<40$ years } & \multicolumn{2}{|c|}{$>40$ years } \\
\hline & & & & $\mathrm{POF}+$ & POF- & $\mathrm{POF}+$ & POF- \\
\hline 1 & 58.25 & 13.0 & 31 & & & 2 & \\
\hline 2 & 41.68 & 11.0 & 28 & & & & \\
\hline 3 & 31.00 & 12.0 & 30 & & & & 1 \\
\hline 4 & 37.42 & 14.0 & 29 & & & & \\
\hline 5 & 28.58 & 11.0 & 13 & & 3 & & \\
\hline 6 & 39.50 & 14.0 & 37 & & 1 & & 2 \\
\hline 7 & 49.92 & 12.0 & 34 & & 1 & & 1 \\
\hline 8 & 31.75 & 12.5 & 17 & 1 & 1 & & 1 \\
\hline 9 & 40.25 & 13.0 & 35 & & 1 & 1 & \\
\hline 10 & 41.08 & 12.0 & 38 & & 1 & & \\
\hline 11 & 40.67 & 13.0 & 14 & 2 & & & 1 \\
\hline 12 & 43.42 & 9.0 & 28 & & & & 1 \\
\hline 13 & 39.08 & 12.0 & 35 & & & & \\
\hline 14 & 48.33 & 9.0 & 30 & & & 1 & \\
\hline \multirow[t]{2}{*}{$\mathrm{N}=14$} & 40.78 & 12.11 & 28.5 & 3 & 8 & 4 & 7 \\
\hline & SD 7.82 & SD 1.64 & SD 8.19 & \multicolumn{2}{|c|}{11} & \multicolumn{2}{|c|}{11} \\
\hline
\end{tabular}

above the $1 \%$ frequency of premature menopause in the population (Coulam et al., 1986). These results agree with previous surveys, the most extensive being a collaborative study engaging nine centers in different countries, including Brazil (Allingham-Hawkins et al., 1999). Since the fully mutated women, who produce less protein than normal females, do not present ovarian impairment, the observed effect among premutated women should result from function gain for the FMR1 gene product. Murray et al. (1996) suggested that an FRMP isoform could be inappropriately expressed in the fetal ovary of the premutated females. Another possibility, as we have already mentioned, is that the premutation affects nearby genes for ovarian function (Vianna-Morgante et al., 1996). The existence of such genes in the vicinity of the FMR1 locus is indicated by Xq distal deletions described in females with POF (Fitch et al., 1982; Krauss et al., 1987).

Our data suggests that POF clusters in certain fragile $\mathrm{X}$ families, a possibility deserving further investigation and, if confirmed, indicating the peculiarity of some premutations or of the genes they influence. On the other hand, we observed that premutated women as a group experienced menopause earlier than their noncarrier relatives, indicating a more general effect of the premutation, possibly ranging from subtle endocrinological disfunctions to POF. The demonstration by Braat et al (1999) of disturbances in the endocrine profiles in 8 out of 9 menstruating premutated females supports this point of view.

The association of the fragile $\mathrm{X}$ premutation with POF is supported by a satisfactory amount of evidence. Premutated females need this information for both family planning and preventing menopausal complications.

\section{ACKNOWLEDGMENTS}

Research partially supported by FAPESP, CNPq, FINEP and PRONEX. Publication supported by FAPESP.

\section{RESUMO}

Entrevistamos 193 mulheres de famílias com afetados pela síndrome do cromossomo $\mathrm{X}$ frágil, quanto a sua história ginecológica e reprodutiva. Entre as 101 portadoras da prémutação, 14 tiveram menopausa precoce, mas nenhuma das 37 portadoras da mutação completa ou das 55 não portadoras apresentaram esta anomalia. Observamos uma tendência para a concentração da menopausa precoce em certas famílias, o que poderia significar uma peculiariedade de certas pré-mutações. Entretanto, o fato de as mulheres pré-mutadas tenderem a entrar em menopausa mais cedo do que as não portadoras sugere que a menopausa precoce seja o extremo do espectro de efeitos ovarianos da pré-mutação.

\section{REFERENCES}

Allingham-Hawkins, D.J., Babul-Hirji, R., Chitayat, D., Holden, J.J.A., Yang, K.T., Lee, C., Hudson, R., Gorwill, H., Nolin, S.L., Glicksman, A., Jenkins, E.C., Brown, W.T., Howard-Peebles, P.N., Becchi, C., Cummings, E., Fallon, L., Seitz, S., Black, S.H., Vianna-Morgante, A.M., Costa, S.S., Otto, P.A., Mingroni-Netto, R.C., Murray, A., Webb, J., MacSwinney, F., Dennis, N., Jacobs, P.A., Syrrou, M., Georgiou, I., Patsalis, P.C., Uzielli, M.L., Guarducci, S., Lapi, E., Cecconi, A., Ricci, U., Ricotti, G., Biondi, C., Scarselli, B. and Vieri, F. (1999). Fragile X premutation is a significant risk factor for premature ovarian failure - The International Collaborative POF in Fragile X Study - Preliminary Data. Am. J. Med. Genet. 83: 322-325.

Ashley, C.T., Wilkinson, K.D., Reines, D. and Warren, S.T. (1993). FMR1 protein: conserved RNP family domains and selective RNA binding. Science 262: 563-568. 
Braat, D.D.M., Smits, A.P.T. and Thomas, C.M.G. (1999). Menstrual disorder and endocrine profiles in fragile $\mathrm{X}$ carriers prior to 40 years of age: a pilot study. Am. J. Med. Genet. 83: 327-328.

Coulam, C.B., Adamson, S.C. and Annegers, J.F. (1986). Incidence of premature ovarian failure. Obstet. Gynecol. 67: 604-606.

Cronister, A., Schreiner, R., Wittenberger, M., Amiri, K., Harris, K. and Hagerman, R.J. (1991). Heterozygous fragile X female: Historical, physical, cognitive, and cytogenetic figures. Am. J. Med. Genet. 38: 269-274.

Fitch, N., de Saint Victor, J., Richer, C.-L., Pinsky, L. and Sitahal, S. (1982). Premature menopause due to a small deletion in the long arm of the X chromosome: a report of three cases and a review. Am. J. Obstet. Gynecol. 142: 968-972.

Krauss, C.M., Turksoy, R.N., Atkins, L., McLaughlins, C., Brown, L.G. and Page, D.C. (1987). Familial premature ovarian failure due to an interstitial deletion of the long arm of the $\mathrm{X}$ chromosome. N. Engl. J. Med. 317: 125-131.

Mattison, D.R., Evans, M.I., Schwimmer, W.B., White, B.J., Jensen, B. and Schulman, J.D. (1984). Familial premature ovarian failure. Am. J. Hum. Genet. 36: 1341-1348.

Mingroni-Netto, R.C., Fernandes, J.G. and Vianna-Morgante, A.M.
(1994). Relationship of expansion of CGG repeats and X-inactivation with expression of $\mathrm{fra}(\mathrm{X})(\mathrm{q} 27.3)$ in heterozygotes. Am. J. Med. Genet. 51: 443-446.

Murray, A., Conway, G.S. and Jacobs, P.A. (1996). Premature ovarian failure and fragile X. Am. J. Med. Genet. 64: 15-20.

Oberlé, I., Rousseau, F., Heitz, D., Kretz, C., Devys, D., Hanauer, A., Boué, J., Bertheas, M.F. and Mandel, J.L. (1991). Instability of a 550-base pair DNA segment and abnormal methylation in fragile $\mathrm{X}$ syndrome. Science 252: 1097-1102.

Pieretti, M., Zhang, F., Fu, Y.H., Warren, S.T., Oostra, B.A., Caskey, C.T. and Nelson, D.L. (1991). Absence of expression of the FMR-1 gene in fragile X syndrome. Cell 66: 817-822.

Schwartz, C.E., Dean, J., Howard-Peebles, P.N., Bugge, M., Mikkelsen, M., Tommerup, N., Hull, C., Hagerman, R., Holden, J.J.A. and Stevenson, R.E. (1994). Obstetrical and gynecological complications in fragile X carriers: a multicenter study. Am. J. Med. Genet. 51: 400-402.

Vianna-Morgante, A.M., Costa, S.S., Pares, A.S. and Verreschi, T.N. (1996). FRAXA premutation associated with premature ovarian failure. Am. J. Med. Genet. 64: 373-375.

(Received May 11, 1999) 